\title{
Impact of ligand size and conjugation chemistry on the performance of universal chimeric antigen receptor $T$-cells for tumor killing
}

Christian Pellegrino ${ }^{1}$, Nicholas Favalli ${ }^{1}$, Michael Sandholzer ${ }^{1}$, Laura Volta ${ }^{1}$, Gabriele Bassi ${ }^{1}$, Jacopo Millul ${ }^{2}$, Samuele Cazzamalli ${ }^{2}$, Mattia Matasci ${ }^{2}$, Alessandra Villa ${ }^{2}$, Renier Myburgh ${ }^{3}$, Markus G. Manz $^{3 *}$, Dario Neri $^{1 *}$

Author address:

${ }^{1}$ Department of Chemistry and Applied Biosciences, Swiss Federal Institute of Technology (ETH Zürich),8093 Zurich, Switzerland.

${ }^{2}$ Philochem AG, Libernstrasse 3, 8112 Otelfingen (Switzerland).

${ }^{3}$ Department of Medical Oncology and Hematology, University Hospital Zurich and University of Zürich, 8091 Zürich, Switzerland, Comprehensive Cancer Center Zurich (CCCZ).

\section{Supplementary information}


Index

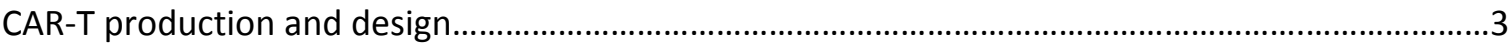

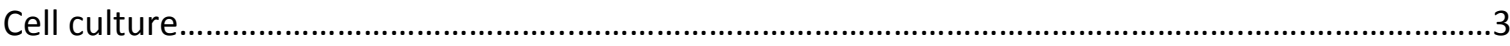

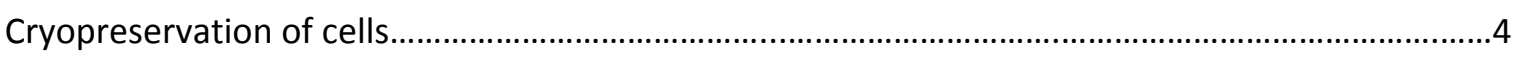

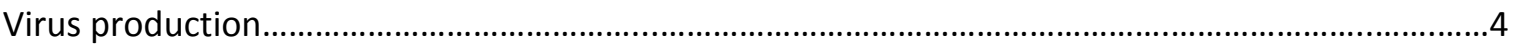

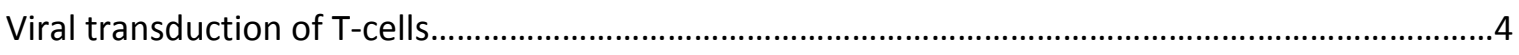

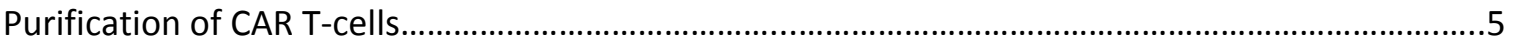

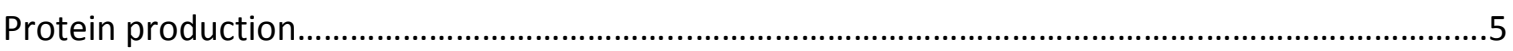

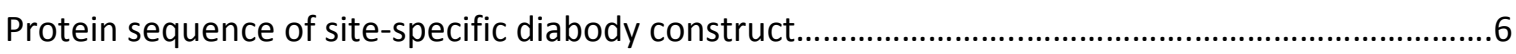

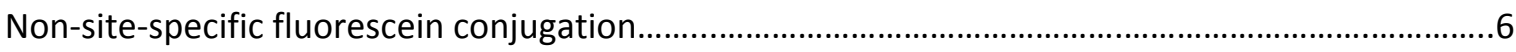

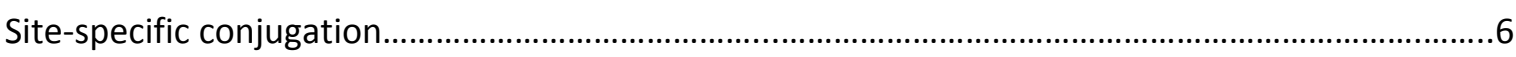

Determination of dissociation constants....................................................................................

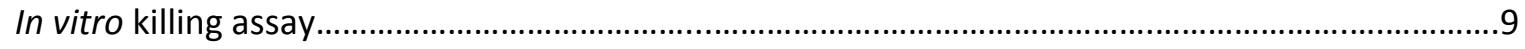

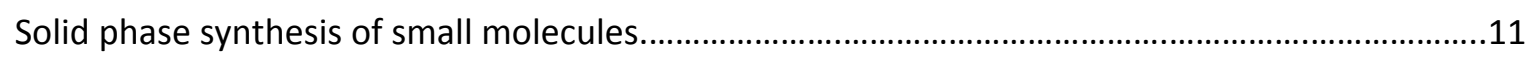

Amino-acid and carboxylic acid coupling procedure.......................................................................11

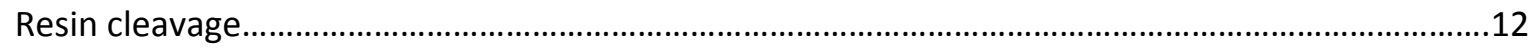

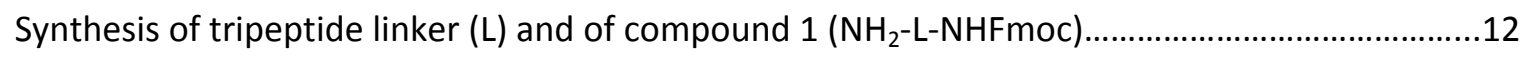

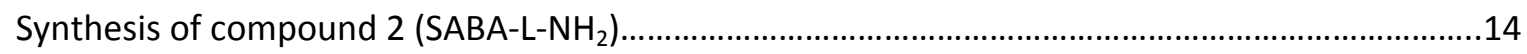

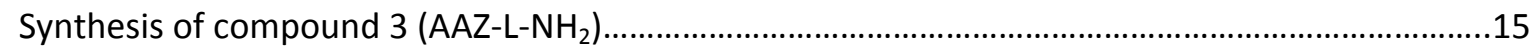

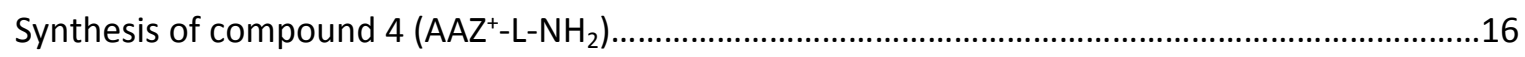

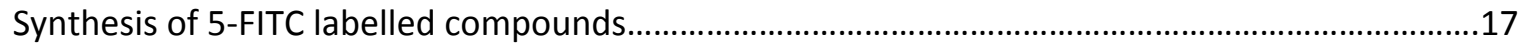

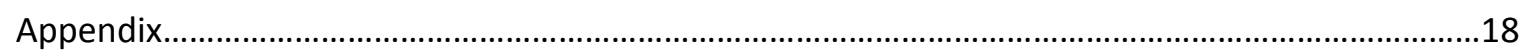

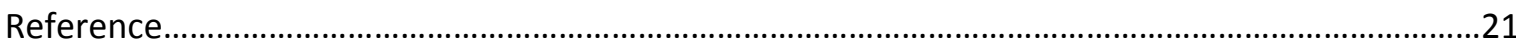




\section{CAR-T production and design}

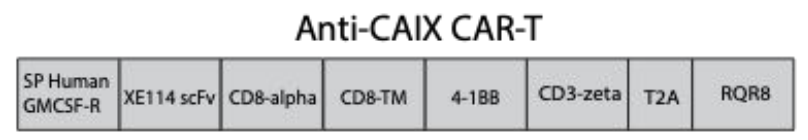

Transduction of CD4+ CD8+ T-cells
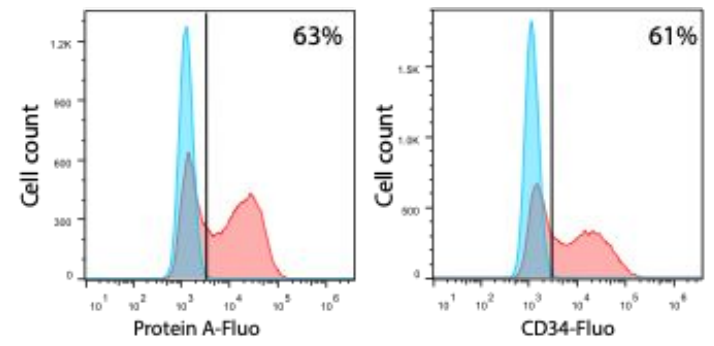

Purification of anti-CAIX CAR-T
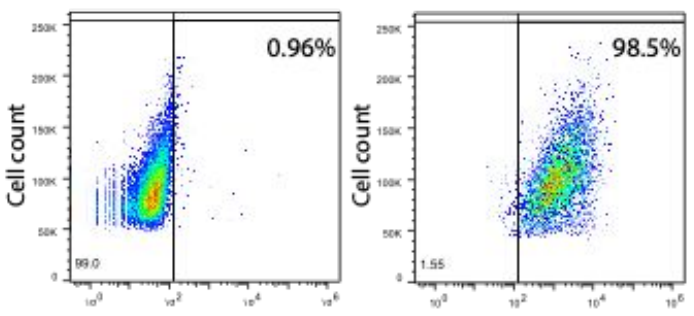

CD34-Fluo on untranduced T-cells (\%)

CD34-Fluo on purified population (\%)
Anti-fluorescein (4M5.3) UniCAR-T

\begin{tabular}{|l|l|l|l|l|l|l|l|}
\hline $\begin{array}{l}\text { SP Human } \\
\text { GMCSF-R }\end{array}$ & 4M5.3 scFv & CDB-alpha & CD8-TM & $4-18 B$ & CD3-zeta & T2A & RQR8 \\
\hline
\end{tabular}

Transduction of $\mathrm{CD} 4+\mathrm{CD} 8+\mathrm{T}$-cells
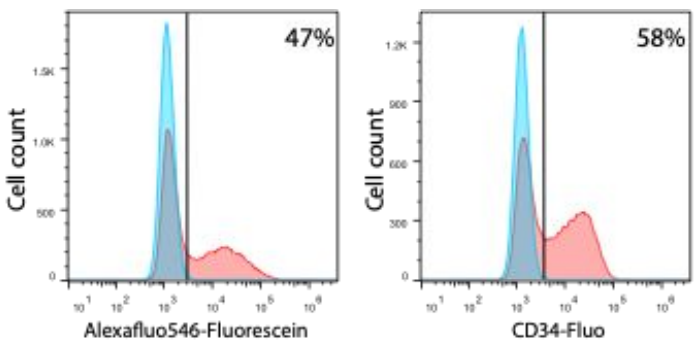

Purification of anti-fluorescein UniCAR-T
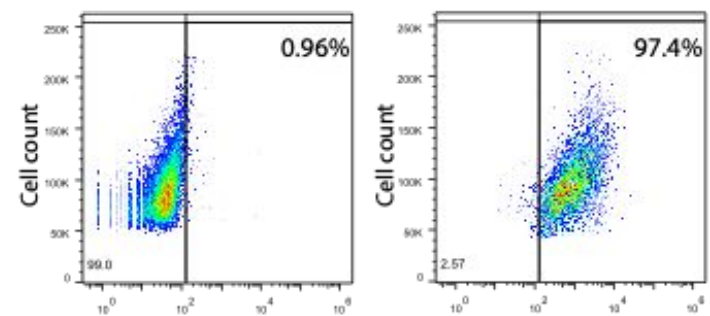

CD34-Fluo on untranduced T-cells (\%) CD34-Fluo on purified population (\%)

Fig S1. The CAR-T design was kept the same for both $\alpha$ CAIX and UniCAR-T constructs. The transduction percentage was 53\% for the $\alpha$ CAIX CAR-T and 57\% for the UniCAR-T. After one week of cell enrichment, the CAR T-cell population was purified via anti-FITC magnetic MACs beads (Miltenyi). The purity obtained was 98.5\% for the $\alpha$ CAIX CAR-T and $97.4 \%$ for the UniCAR-T. After the purification process, the CAR-T were cultured for a week for further enrichment. The cell numbers reached roughly $2 \times 10^{8}$ and were cryopreserved until required.

\section{Cell culture}

HEK293T cells (ATCC $®$ CRL-3216 ${ }^{\mathrm{TM}}$ ) were kept in DMEM media (Gibco), supplemented with 10\% FBS (Gibco, \#10270106), 2mM Glutamine and 1\% antibiotic-antimycoticum (Gibco, \#15240062). Human PBMCs were kindly provided by Cerus (Intercept blood systems, California, USA). T-cells were expanded in Advanced RPMI (Gibco) supplemented with 10\% FBS (Gibco, \#10270106), 2mM Ultraglutamate (Lonza, \#BE17-605E/U1), 1\% antibioticantimycoticum (Gibco, \#15240062) and $100 \mathrm{UI}$ of human IL-2/ml (Proleukin, Roche Diagnostics). SK-RC-52 cells were kindly provided by Professor E. Oosterwijk (Radbound University Nijmegen Medical Centre, Nijmegen, the Netherlands) and expanded in RPMI-1640 media (Gibco, \#21875034) supplemented with 10\% FBS (Gibco, \#10270106) and 1\% Anti-Anti 
(Gibco, \#15240062). The cells were detached through each passage step via EDTA-Trypsin 0.05\% (Invitrogen).

\section{Cryopreservation of cells}

Cryopreservation of cells was performed as recommended by ATCC $\AA$. For CAR T-cell cryopreservation, $10 \times 10^{6}$ cells were frozen in $1 \mathrm{~mL}$ of freezing media (composed of $90 \%$ FBS and $10 \%$ Dimethyl sulfoxide (Sigma-Aldrich)) and transferred to cryovials (Greiner Bio-one). Vials were put in Mr Frosty (Nalgene, Sigma-Aldrich) and transferred to $-80^{\circ} \mathrm{C}$. After 3 days, Tcells were then transferred to liquid nitrogen tanks and stored until further use.

\section{Virus production}

HEK293T-cells were seeded at a density of $5 \times 10^{6}$ in $15 \mathrm{~mL}$ of complete DMEM media (as previously described) in a T75 cell culture flask.

The sPAX2 packaging and PCAG-VSVG envelope plasmids were both kindly provided by Dr. Patrick Salmon (University of Geneva, Switzerland). The Lentiviral plasmid (pCDH-EF1 $\alpha-M C S-$ T2A-GFP; System Biosciences, Palo Alto, CA, USA) was cloned into the EF1 $\alpha$-CAR-T2A-RQR8 backbone that was provided by Dr Renier Myburgh and Prof Dr Markus G Manz ${ }^{1}$. The EF1-UniCAR-T2A-RQR8 was cloned using restriction sites Nhel (NEB) and Xhol (NEB) to insert the scFv 4M5.32. The RQR8 sequence was kindly provided by Dr Brian Philip and Dr Martin Pule and was inserted as a marker for expression ${ }^{3}$. The transfection mixture was added to the HEK293T cells and incubated at $37^{\circ} \mathrm{C}$ and $5 \% \mathrm{CO}_{2}$. The media was exchanged the next morning with fresh medium and the virus was harvested the following day. To harvest the virus the supernatant was transferred to a $50 \mathrm{ml}$ Falcon tube and spun ( $400 \mathrm{~g}, 5 \mathrm{~min}, \mathrm{RT}$ ) and filtered using $0.45 \mu \mathrm{m}$ filter (TPP, Switzerland) to remove cells and debris. To concentrate the virus, PEG-it (System Biosciences, CA, USA) was added according to the manufacturer's instructions and samples incubated overnight at $4^{\circ} \mathrm{C}$. The next morning, samples were centrifuged $\left(1500 \mathrm{~g}, 30 \mathrm{~min}, 4^{\circ} \mathrm{C}\right)$. After aspirating the supernatant, the pellet was centrifuged again $\left(1500 \mathrm{~g}, 30 \mathrm{~min}, 4^{\circ} \mathrm{C}\right)$ to remove residual supernatant. The pellet was resuspended in $1 / 200$ of the original volume and stored at $-80^{\circ} \mathrm{C}$ until further use. 


\section{Viral transduction of T-cells}

Human T-cells were activated in T-cell media using CD3/CD28 Dynabeads (ThermoFisher) the day prior to transduction. For the transduction, Polybrene (Santa Cruz Biotechnology, \#134220) was added to a final concentration of $8 \mu \mathrm{g} / \mathrm{mL}$ and $10 \mu \mathrm{L}$ virus supernatant was added on the cells and mixed. After centrifugation $\left(1000 \mathrm{~g}, 90 \mathrm{~min}, 37^{\circ} \mathrm{C}\right)$ the cells were incubated overnight $\left(37^{\circ} \mathrm{C}, 5 \% \mathrm{CO}_{2}\right)$. At the following day, the media was exchanged, and the T-cells were incubated overnight $\left(37^{\circ} \mathrm{C}, 5 \% \mathrm{CO}_{2}\right)$. The beads were removed using a magnet incubate for $2 \mathrm{~min}$ and centrifuged the supernatant $\left(400 \mathrm{~g}, 5 \mathrm{~min}, 37^{\circ} \mathrm{C}\right)$. The pellets were then resuspended in fresh T-cell media and expand them at $0.5 \times 10^{6}$ cells $/ \mathrm{mL}$. Once the population of transduced T-cells reached roughly $2 \times 10^{7}$, the CAR T-cells were purified via magnetic cell sorting.

\section{Purification of CAR T-cells via magnetic cell sorting}

The transduced T-cells were centrifuged $\left(400 \mathrm{~g}, 5 \mathrm{~min}, 4^{\circ} \mathrm{C}\right)$ and resuspended in $10 \mathrm{~mL} \mathrm{MACS}$ buffer ( 2 mM EDTA and 0.5\% FBS in PBS). After counting the cells, they were centrifuged (400 g, $5 \mathrm{~min}, 4^{\circ} \mathrm{C}$ ) again and resuspended in $10 \mu \mathrm{L}$ MACS buffer per $1 \times 10^{6}$ cells. Anti-CD34 antibody coupled with FITC (QBEND-10, Sigma-Aldrich) was added in a 1:20 dilution to the cells and incubated for $30 \mathrm{~min}$ at $4^{\circ} \mathrm{C}$ in the dark. Then, $25 \mathrm{~mL}$ MACS buffer was added, and cells were spun down $\left(400 \mathrm{~g}, 5 \mathrm{~min}, 4^{\circ} \mathrm{C}\right)$. The supernatant was aspirated, and cells were resuspended in $10 \mu \mathrm{L}$ MACS buffer per $1 \times 10^{6}$ cells. Anti-FITC magnetic micro beads (Miltenyi Biotech) were added in a dilution of 1:10. Cells were incubated with the beads for $30 \mathrm{~min}$ at $4^{\circ} \mathrm{C}$ and washed using $25 \mu \mathrm{L}$ MACS buffer. Cells were spun down $\left(400 \mathrm{~g}, 5 \mathrm{~min}, 4^{\circ} \mathrm{C}\right)$, supernatant removed, and cells resuspended in $500 \mu \mathrm{L}$ MACS buffer. In the meantime, magnetic columns (Miltenyi Biotech) were put in magnetic separators (Miltenyi Biotech) and equilibrated using $3 \mathrm{~mL}$ MACS buffer. The transduced T-cell mixture was added onto the column trough a cell strainer (Miltenyi Biotech). The column was washed three times using $3 \mathrm{~mL}$ of MACS buffer per washing step. After the washing, the column was taken out of the magnetic separator and T-cells eluted in $5 \mathrm{~mL}$ MACS buffer. A small aliquot was taken for cell counting as well as subsequent flow cytometry analysis of the purified T-cell population. Purified CAR T-cells were then resuspended in $1 \mathrm{~mL}$ T-cell media per $1 \times 10^{6}$ cells and expanded until reaching sufficient cell numbers. 


\section{Protein production}

Proteins were produced by transient transfection of $\mathrm{CHO}-\mathrm{S}$ cells and purified by protein-A affinity chromatography as described previously ${ }^{4-6}$. The XE114 (anti-CAIX IgG with mutated cysteines) was previously cloned in our laboratory and published ${ }^{7}$. The diabody was cloned to contain the sequences of the VH and VL of the XE114 antibody with a 5-amino acid linker (GGSGG). The sequence was cloned in pcDNA 3.1 and produced using the same protocol referenced above.

\section{Protein sequence of the site-specific diabody construct}

The full sequence for the $\mathrm{C}$-terminus modified cysteine is shown below. The terminal serine residue on the heavy chain was modified to a cysteine.

\section{Light chain:}

SSELTQDPAVSVALGQTVRITCQGDSLRSYYASWYQQKPGQAPVLVIYGKNNRPSGIPDRFSGSSSGNTA SLTITGAQAEDEADYYCQSSKWSWDPVVFGGGTKLTVLG

Heavy chain:

EVQLLESGGGLVQPGGSLRLSCAASGFTFSSYAMSWVRQAPGKGLEWVSAIDGSGGSTYYADSVKGRF TISRDNSKNTLYLQMNSLRAEDTAVYYCVKGPPVFDYWGQGTLVTVㅡㅗ

\section{Non-site-specific fluorescein conjugation}

The protein sample with a concentration of $2 \mathrm{mg} / \mathrm{mL}$ was dialyzed against $0.1 \mathrm{M} \mathrm{NaCO}_{3}(\mathrm{pH}$ 9) overnight at $4^{\circ} \mathrm{C}$. The Fluorescein isothiocyanate (Sigma-Aldrich) was dissolved in DMSO (3 $\mathrm{mg}$ in $3 \mathrm{~mL}$ ) to obtain a final concentration of $10 \%(\mathrm{v} / \mathrm{v})$ when added to the protein. The mixture was incubated for $8 \mathrm{~h}$ at $4^{\circ} \mathrm{C}$ in a $360^{\circ}$ rotator. After that, the protein was purified by a PD-10 size exclusion column (GE Healthcare). The collected fractions containing the product were pooled. Protein aliquots were snap frozen and stored at $-80^{\circ} \mathrm{C}$ until further use.

\section{Site-specific fluorescein conjugation}

A $1.0 \mathrm{mg} / \mathrm{mL}$ antibody (IgG or diabody) solution was reduced with $20 \mathrm{mM}$ of DTT (1,4-DithioDL-threitol) in PBS ( $\mathrm{pH}=7.4$ ) overnight. Complete reduction of the cysteines was monitored by mass Spectrometry. After reduction, the protein was added to a Vivaspin centrifugation concentrator (Sartorius) and $4 \mathrm{~mL}$ of PBS $(\mathrm{pH}=7.4)$ were added to dilute the DTT (centrifuged at $4000 \mathrm{~g}, 20 \mathrm{~min}, 4^{\circ} \mathrm{C}$ ). After three washing steps, the protein solution was adjusted to a final 
concentration of approximately $1.0 \mathrm{~g} / \mathrm{mL}$ and moved to an Eppendorf reaction tube. Commercially available fluorescein-5-maleimide (30 eq.) was dissolved in DMSO (SigmaAldrich) $(4.3 \mathrm{mg}$ in $1 \mathrm{~mL})$ to obtain a final concentration of $10 \%(\mathrm{v} / \mathrm{v})$ when added to the reduced protein. The mixture was stirred for 1 hour at RT. The completion of conjugation was proofed by mass Spectrometry. The final product was purified by PD-10 size exclusion column (GE Healthcare). Fraction containing protein were pooled and the final protein was concentrated using Vivaspin centrifugation concentrator (Sartorius). Protein aliquots were snap frozen and stored at $-80^{\circ} \mathrm{C}$ until further use.

To calculate the fluorescein:protein ratios the following formula was used:

$$
\mathrm{F}: \mathrm{P}=\left(3.3 \times O D^{495}\right)+[O D 280-(0.35 \times O D 495)]
$$

Equation 1: The equation gives a value quantifying the average number of fluorescein molecules per protein molecule.

\section{Determination of dissociation constants}

The dissociation constant of the targeting ligands was investigated on SK-RC-52 cells via flow cytometry analysis. Media was removed from cell culture dishes and cells were washed with PBS (Gibco). Per $25 \mathrm{~cm}^{2}$ surface area $1 \mathrm{~mL}$ Accutase (Sigma-Aldrich) was added to detach the cells from the flask. The cells were spun down ( $400 \mathrm{~g}, 5 \mathrm{~min}, \mathrm{RT})$ and resuspended in FACS buffer (PBS (Gibco), 1\% Bovine Serum Albumin (Sigma-Aldrich), 2 mM EDTA (Janssen Pharmaceuticals)), strained ( $35 \mu \mathrm{m}$ nylon mesh) and incubated for $30 \mathrm{~min}$ on ice. Triplicates were performed for every concentration of targeting ligand. Therefore, 150 '000 cells in 100 $\mu \mathrm{L}$ per well were distributed in a round bottom 96 well plate (Cellstar, Greiner Bio One) and spun down $\left(400 \mathrm{~g}, 5 \mathrm{~min}, 4^{\circ} \mathrm{C}\right)$. The supernatant was removed by flicking, and the pellets were resuspended in FACS buffer containing different concentrations of targeting ligands. The samples were incubated for $1 \mathrm{~h}$ in the dark on ice. Subsequently, the cells were centrifuged $\left(400 \mathrm{~g}, 5 \mathrm{~min}, 4^{\circ} \mathrm{C}\right)$, and the supernatant removed. The washing step was repeated once for small molecules and three times for antibody derivatives. Finally, the pellet was resuspended in $200 \mu \mathrm{L}$ of FACS buffer and analysed gating for FITC channel by Cytoflex flow cytometer (Beckman Coulter Life Sciences). The flow cytometry data was analysed using FlowJo software (Treestar). 
The concentration of CAIX in FACs was calculated to be approximately in the subnanomolar range $(0.21 \mathrm{nM})$. The equation used to determine the concentration is shown below:

$$
\begin{gathered}
n_{\text {CAIX }}=\frac{N_{\text {cells }} \times N_{\text {CAIX/cell }}}{N_{A}} \\
{\left[\text { CAIX] }=\frac{n_{\text {CAIX }}}{V}\right.}
\end{gathered}
$$

Where:

$\mathrm{N}_{\text {cells }}=$ total number of cells $\left(150^{\prime} 000\right)$,

$\mathrm{N}_{\text {CAIX/cell }}=$ average number of molecules of CAIX for each SKRC52 cell $\left(84^{\prime} 700\right)^{8}$, $\mathrm{N}_{\mathrm{A}}=$ Avogadro's number $\left(6.022 \times 10^{23}\right)$,

$\mathrm{n}_{\text {CAIX }}=$ mol of CAIX, $\mathrm{V}=$ volume of FACS buffer $(100 \mu \mathrm{L})$.

The dissociation constants for acetazolamide (AAZ) and the IgG (XE114) were analysed by BIAcore 3000 (Biacore) to visualize the $\mathrm{K}_{\text {off }}$ and $\mathrm{K}_{\text {on }}$ interactions in binding to CAIX. A total of 2'100 response units (RU) of recombinant His-tagged CAIX were immobilized onto a CM5 chip (Biacore). For this purpose, $15 \mu \mathrm{l}$ of each supernatant was allowed to flow over the coated chip at a flow rate of $10 \mu \mathrm{l} / \mathrm{min}$. 

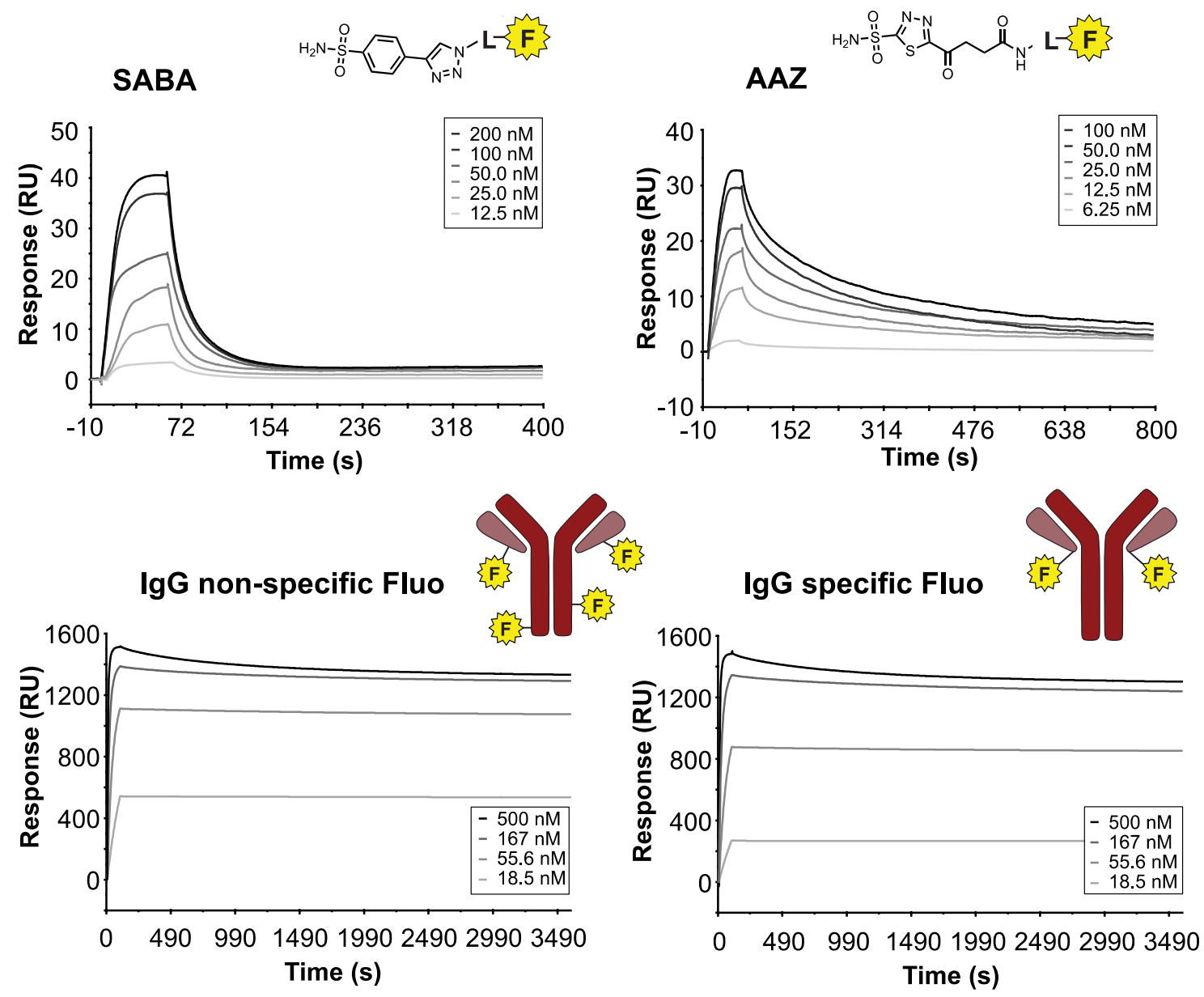

\begin{tabular}{cccc}
\hline & $K_{\text {on }}(\mathbf{1} / \mathrm{Ms})$ & $K_{\text {off }}(\mathbf{1} / \mathbf{s})$ & $\mathrm{K}_{d}(\mathrm{M})$ \\
\hline SABA & $5.470 \cdot 10^{+5}$ & 0.05844 & $1.1 \cdot 10^{-7}$ \\
AAZ & $1.688 \cdot 10^{+6}$ & 0.005613 & $3.3 \cdot 10^{-9}$ \\
Non-specific Fluo IgG & $2.333 \cdot 10^{+5}$ & $1.915 \cdot 10^{-5}$ & $8.2 \cdot 10^{-11}$ \\
Spcific Fluo IgG & $2.141 \cdot 10^{+5}$ & $1.265 \cdot 10^{-5}$ & $5.9 \cdot 10^{-11}$
\end{tabular}

Fig S2. The BIAcore profiles for SABA and AAZ demonstrate their differences in Koff and Kon. In the lower part of the figure is depicted the BIAcore profile of the Ig $G$ non-specific fluo and Ig $G$ specific fluo conjugation.

\section{In vitro Killing assay}

UniCAR T-cells, aCAIX CAR T-cells and non-transduced T-cells were thawed and grown in culture of $1 \times 10^{6}$ cells per ml Advanced RPMI (Gibco) without IL-2 (Proleukin, Roche Diagnostics). On day 0, SK-RC-52 cells were harvested and membrane stained using PKH26 Red Fluorescent Cell Linker Kit for General Membrane (Sigma-Aldrich) following manufacturer instructions. After the staining procedure was completed, the stained SK-RC-52 cells were 
seeded at a density of $30^{\prime} 000$ cells per well, in a 96 well plate and incubated overnight $\left(37^{\circ} \mathrm{C}\right.$, $5 \% \mathrm{CO}_{2}$ ). The next day, SK-RC-52 cells in extra wells were detached and counted. T-cells or UniCAR-Ts were resuspended in $100 \mu \mathrm{L}$ Advanced RPMI (Gibco) containing different concentrations of bispecific adapters and added on the SK-RC-52 cells in a 1:1 target to effector cell ratio. Anti CAIX CAR-Ts and non-transduced T-cells served as a positive and negative control respectively. After addition, the plate was spun down ( $400 \mathrm{~g}, 1 \mathrm{~min}, \mathrm{RT}$ ) and incubated for $24 \mathrm{~h}\left(37^{\circ} \mathrm{C}, 5 \% \mathrm{CO}_{2}\right)$. The killing rate was assessed for the different condition via FACS. Therefore, the supernatant was transferred to a round bottom 96 well plate. After washing the wells with $100 \mu \mathrm{L}$ of PBS, the PBS was also collected. Then, $50 \mu \mathrm{L}$ Accutase (Millipore) was added to each well and incubated for 5 minutes at $37^{\circ} \mathrm{C}$ to detach the target cells. The detached cells were added to the corresponding well of the round bottom 96 well plate. The plate was spun down ( $400 \mathrm{~g}, 5 \mathrm{~min}, \mathrm{RT})$, flicked to remove the supernatant and the pellets were resuspended in $150 \mu \mathrm{L}$ FACS buffer. After $30 \mathrm{~min}$ of incubation with the FACS buffer at $4^{\circ} \mathrm{C}$ in the dark, the cells were spun down ( $\left.400 \mathrm{~g}, 5 \mathrm{~min}, 4^{\circ} \mathrm{C}\right)$. Immediately before measurement, the pellets were resuspended in a 1:10'000 dilution of the live/dead staining TOTO -3 lodide (ThermoFisher) in FACs buffer, strained (30 $\mu$ m nylon mesh) and analyzed via flow cytometry (Cytoflex, Beckman Coulter). The flow cytometry data was analyzed using FlowJo software (Treestar). The figure below illustrates the gating strategy for the cell lysis calculation.
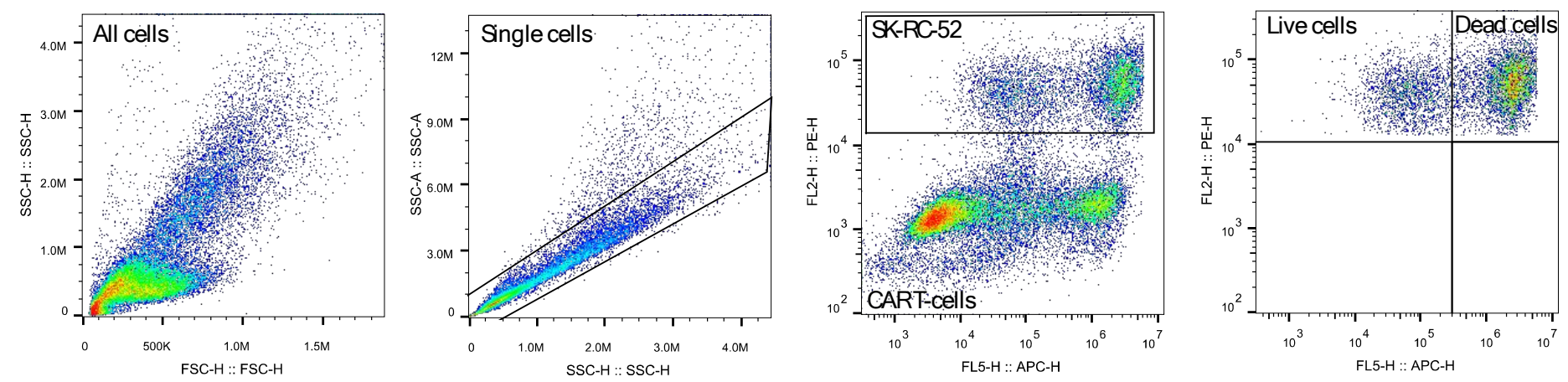

Fig S3. The gating strategies used to determine the UniCAR T-cell induced tumor cell lysis. 

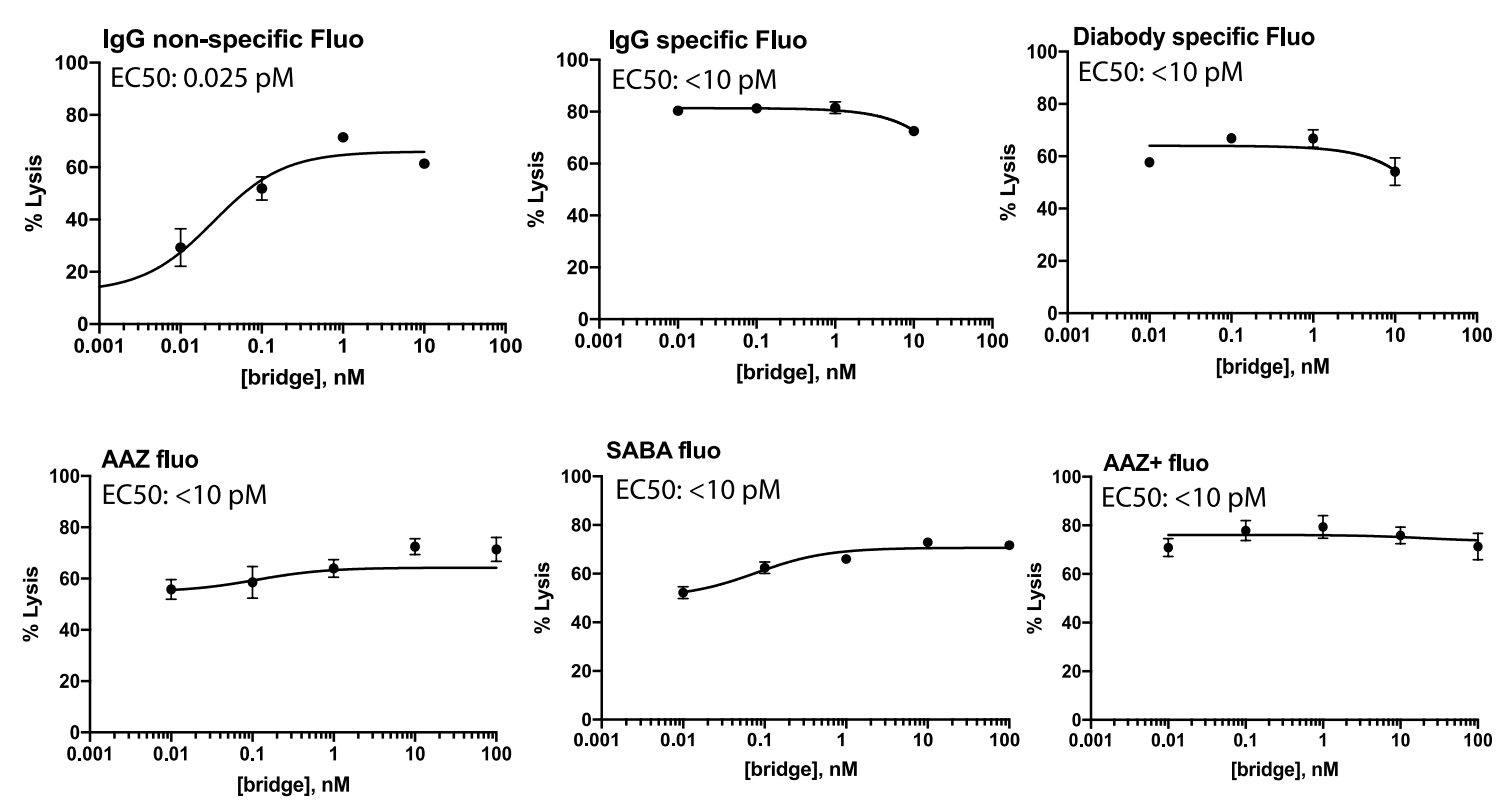

Fig S4. The killing assays were plotted to estimate the EC50 for each bridge construct. The EC5O values reported are an estimation derived from the data achieved in the killing assays reported in Figure 4.

\section{Solid phase synthesis of small molecules "bridges"}

The synthesis of small molecules bridges was performed on solid phase using pre-loaded Fmoc-Lys(Boc) on Wang resin (0.5 mmol/g, REF, Bachem).

Fmoc Deprotection procedure. The Fmoc protecting group was removed by treating the resin three times with piperidine:DMF=1:4 solution ( $20 \mathrm{~mL} / \mathrm{g}, 1 \times 30$ minutes, $2 \times 10$ minutes). After deprotection, the resin was washed several times with fresh DMF.

\section{Amino-acid and carboxylic acid coupling procedure}

The deprotected resin was allowed to react for 4 hours with an activated solution of Fmocprotected amino-acid or carboxylic acid (4 equivalents of acid, 4 equivalents of HATU, 8 equivalents of DIPEA) in dry DMF ( $5 \mathrm{~mL} / \mathrm{mmol}$ ). After the coupling reaction, the resin was washed several times with DMF. The coupling performance was confirmed by TNBS test. The TNBS (2,4,6-trinitrobenzenesulfonic acid) test can only be used for detecting primary amino groups. The beads turn orange-red in presence of free primary amino group. Few beads was poured into a solution of 2,4,6-trinitrobenzenesulfonic acid in DMF:DIPEA=9:1 and incubated for 5 minutes. 
Resin cleavage. The resin was treated with cleavage solution (trifluoroacetic acid : $\mathrm{H}_{2} \mathrm{O}$ : triisopropylsilane = 95: $2.5: 2.5,20 \mathrm{ml} / \mathrm{g}$ ) for 1 hour at room temperature. In order to increase the cleavage yield, the procedure was repeated for additional 30 minutes. The TFA solution of cleaved product was poured into cold $\left(-20^{\circ} \mathrm{C}\right)$ diethyl ether and centrifuged at $5000 \mathrm{rpm}\left(-10^{\circ} \mathrm{C}\right)$ for 30 minutes. The supernatant was discarded and the pellet was dried and re dissolved in $1 \mathrm{~mL}$ of $\mathrm{H}_{2} \mathrm{O}$ : Acetonitrile $=1: 1$. The products were purified by RPChromatography on C18 $40 \mu \mathrm{M}$ irregular column (12 g) with $\mathrm{H}_{2} \mathrm{O}$ : Acetonitrile $(0.1 \% \mathrm{FA})$ in concentration gradient as mobile phase. Purified products were lyophilized and characterized by UPLC-MS.

\section{Synthesis of tripeptide linker (L) and of compound 1 ( $\mathrm{NH}_{2}$-L-NHFmoc)}

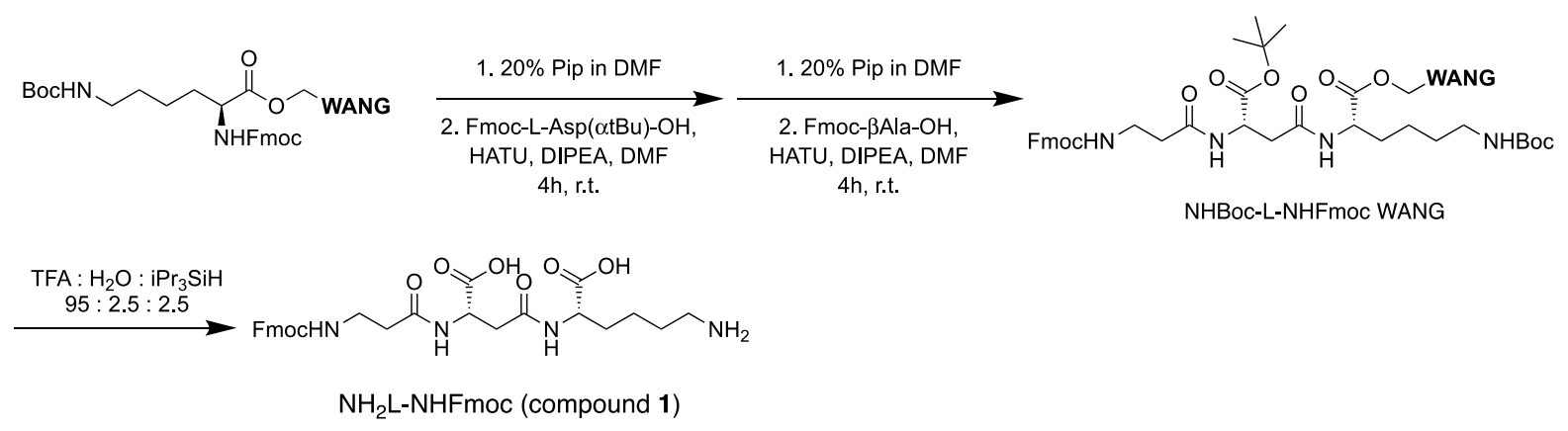

Figure S5. The synthesis of the linker is illustrated above. For each small molecule based bispecific adapter, the same linker was conjugated.

$1.0 \mathrm{~g}$ of commercially pre-loaded Fmoc-Lys(Boc) Wang resin $(0.5 \mathrm{mmol})$ was swollen in DMF (30 mins). The resin was deprotected as previously describe an assembled using the Fmoc-Amino-acid coupling procedure with the following sequence: Aspartic acid ( $\alpha$ tBu ester), $\beta$-Alanine.

The tripeptide $\mathrm{NH}_{2} \mathrm{~L}-\mathrm{NHFmoc}$ (compound 1 ) was obtained by cleaving a portion of Fmocprotected resin $(100 \mathrm{mg}, 0.05 \mathrm{mmol})$ which was subsequentely purified. Yield $=22 \%$. ${ }^{1} \mathbf{H}$ NMR (600 MHz, DMSO-d6) $\delta 8.02(\mathrm{~s}, 1 \mathrm{H}), 7.91-7.87(\mathrm{~m}, 2 \mathrm{H}), 7.69(\mathrm{~d}, J=7.6 \mathrm{~Hz}, 2 \mathrm{H}), 7.45-7.30$ $(\mathrm{m}, 6 \mathrm{H}), 4.33-4.18(\mathrm{~m}, 5 \mathrm{H}), 4.12(\mathrm{td}, J=8.2,4.2 \mathrm{~Hz}, 2 \mathrm{H}), 3.21(\mathrm{dt}, J=9.6,7.1 \mathrm{~Hz}, 3 \mathrm{H}), 2.75(\mathrm{~d}$, $J=7.5 \mathrm{~Hz}, 2 \mathrm{H}), 2.60(\mathrm{~d}, J=10.5 \mathrm{~Hz}, 1 \mathrm{H}), 2.47-2.40(\mathrm{~m}, 1 \mathrm{H}), 2.29(\mathrm{t}, J=7.2 \mathrm{~Hz}, 2 \mathrm{H}), 1.77-1.62$ 
(m, 1H), $1.50(\mathrm{dt}, J=31.6,9.6 \mathrm{~Hz}, 3 \mathrm{H}), 1.43-1.21(\mathrm{~m}, 3 \mathrm{H}) .{ }^{13} \mathrm{C}$ NMR (151 MHz, DMSO) $\delta$ $173.95,173.41,169.83,169.25,163.89,155.91,143.78,142.43,140.56,139.28,137.29$, 128.81, 127.48, 127.18, 126.98, 125.12, 121.27, 119.91, 109.66, 65.33, 51.06, 46.56, 39.80, $38.07,37.16,35.83,30.30,26.06,21.58 . \mathrm{m} / \mathrm{Z}$ calculated for $\mathrm{C}_{28} \mathrm{H}_{34} \mathrm{~N}_{4} \mathrm{O}_{8}: 554.24$, detected (TOF MS ES+): 555.2159 . 


\section{Synthesis of compound 2 (SABA-L-NH ${ }_{2}$ )}

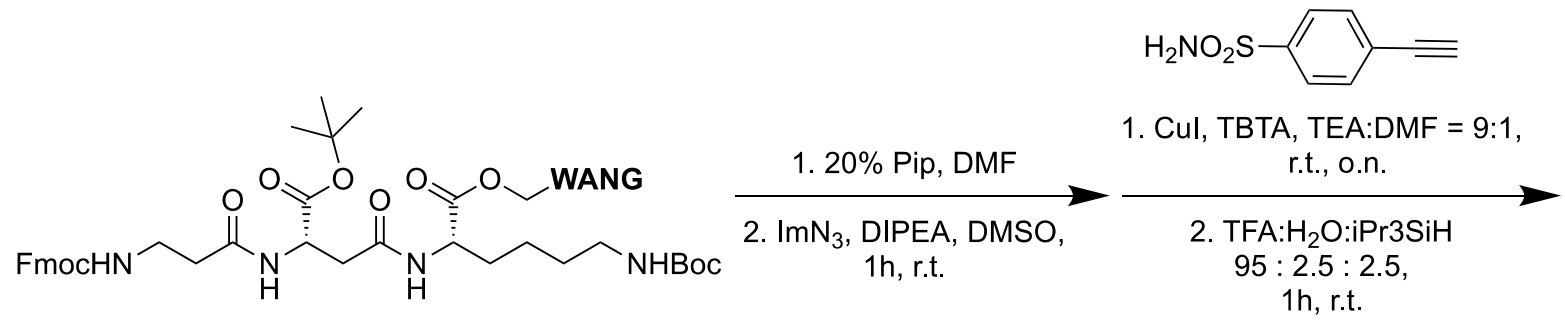

NHBoc-L-NHFmoc WANG<smiles>NCCCC[C@H](NC(=O)C[C@H](NC(=O)CCn1cc(-c2ccc(S(N)(=O)=O)cc2)nn1)C(=O)O)C(=O)O</smiles>

SABA-L-NH 2 (compound 2)

Figure S6. The synthesis steps of SABA-L-NH $\mathrm{H}_{2}$ is reported in this figure.

Pre-synthesized NHBoc-L-NHFmoc WANG resin $(200 \mathrm{mg}, 0.1 \mathrm{mmol}$ ) was deprotected as reported in the general procedure. The free amino derivative was allowed to react with Imidazole-1-sulfonyl azide hydrochloride (51 mg, 0.3 mmol, CAS 952234-37-6) and DIPEA (180 $\mu \mathrm{L})$ for 1 hour at room temperature. The product was washed several times with fresh DMF. Commercially available 4-ethynylbenzenesulfonamide (72 mg, $0.4 \mathrm{mmol}$, CAS 1788-08-5), copper lodide (Cul, 4 mg, $0.02 \mathrm{mmol}$ ), Tris(benzyltriazolylmethyl)amine (TBTA, 0.04 mmol., $21 \mathrm{mg}$ ) were dissolved in $2 \mathrm{~mL}$ of degassed DMF and added to the tripeptide azido-derivative. The reaction was kept overnight at room temperature, then washed several times with EDA $(0.5 \mathrm{M}$ in water, $\mathrm{pH}=8)$ and fresh DMF. The final product $\mathbf{2}\left(\mathrm{SABA}-\mathrm{L}-\mathrm{NH}_{2}\right)$ was cleaved from the resin and purified as previously described. Yield $=32 \% .{ }^{1} \mathbf{H}$ NMR (600 MHz, DMSO-d6) $\delta 8.71$ $(\mathrm{s}, 1 \mathrm{H}), 8.03(\mathrm{dq}, J=8.6,2.2 \mathrm{~Hz}, 2 \mathrm{H}), 7.91-7.84(\mathrm{~m}, 2 \mathrm{H}), 7.39(\mathrm{~s}, 2 \mathrm{H}), 4.63(\mathrm{t}, J=6.8 \mathrm{~Hz}, 2 \mathrm{H})$, $4.30(\mathrm{dt}, J=7.7,5.6 \mathrm{~Hz}, 1 \mathrm{H}$ ), 4.14 (ddd, $J=9.4,7.9,4.3 \mathrm{~Hz}, 1 \mathrm{H}), 2.82(\mathrm{t}, J=6.7 \mathrm{~Hz}, 2 \mathrm{H}$ ), $2.75(\mathrm{t}$, $J=6.8 \mathrm{~Hz}, 2 \mathrm{H}), 2.61-2.56(\mathrm{~m}, 1 \mathrm{H}), 2.44(\mathrm{dd}, J=14.2,5.9 \mathrm{~Hz}, 1 \mathrm{H}), 1.81-1.26(\mathrm{~m}, 8 \mathrm{H}) .{ }^{13} \mathrm{C}$ NMR (151 MHz, DMSO) $\delta 173.67,172.96,169.72,168.11,144.84,142.87,133.89,126.26,125.21$, $122.57,51.50,50.84,46.09,38.07,37.79,35.28,30.05,25.96,21.70 . \mathrm{m} / \mathrm{Z}$ calculated for $\mathrm{C}_{21} \mathrm{H}_{29} \mathrm{~N}_{7} \mathrm{O}_{8} \mathrm{~S}: 539.18$, detected (TOF MS ES+): 540.1931. 


\section{Synthesis of compound 3 (AAZ-L-NH $\left.{ }_{2}\right)$}<smiles>CC(C)(C)OC(=O)NCCCC[C@H](NC(=O)C[C@H](NC(=O)CCNC(F)(F)C(C)(C)C)C(=O)OC(C)(C)C)C(=O)OC(C)(C)C</smiles>

NHBoc-L-NHFmoc WANG

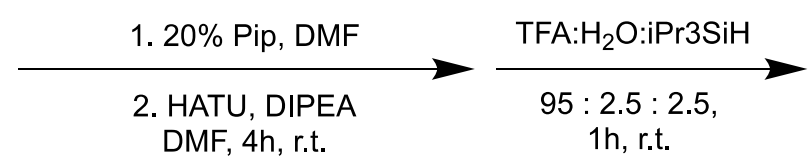

$\left.\prod_{\mathrm{O}}^{\mathrm{HO} \mathrm{O}_{2} \mathrm{C} \sim} \underset{\mathrm{N}-\mathrm{N}}{\mathrm{H}} \mathrm{T}^{\mathrm{S}}\right\rangle \mathrm{SO}_{2} \mathrm{NH}_{2}$<smiles>NCCCC[C@H](NC(=O)C[C@H](NC(=O)CCNC(=O)CCC(=O)Nc1nnc(S(N)(=O)=O)s1)C(=O)O)C(=O)O</smiles>

AAZ-L-NH 2 (compound 3)

Figure S7. A schematic representation of the synthesis steps of AAZ-L-NH $\mathrm{H}_{2}$ are shown.

Pre-synthesized NHBoc-L-NHFmoc WANG resin $(200 \mathrm{mg}, 0.1 \mathrm{mmol}$ ) was deprotected as reported in the general procedure. A solution of 4-oxo-4-((5-sulfamoyl-1,3,4-thiadiazol-2yl)amino)butanoic acid (AAZ-CO $\left.{ }_{2} \mathrm{H}, 95 \mathrm{mg}, 0.4 \mathrm{mmol}, \mathrm{CAS}: 113411-20-4\right)$ was added to the resin and coupled as reported in the general procedure. The final product $\mathbf{3}$ was cleaved and purified as previously described. Yield $=34 \% \mathrm{~m} / \mathbf{z}$ calculated for $\mathrm{C}_{19} \mathrm{H}_{30} \mathrm{~N}_{8} \mathrm{O}_{10} \mathrm{~S}_{2}=$ $594.15 \mathrm{~g} / \mathrm{mol}$; Mass detected (MS TOF ES + ) = 595.2102. 


\section{Synthesis of compound $4\left(\mathrm{AAZ}^{+}-\mathrm{L}-\mathrm{NH}_{2}\right)$}

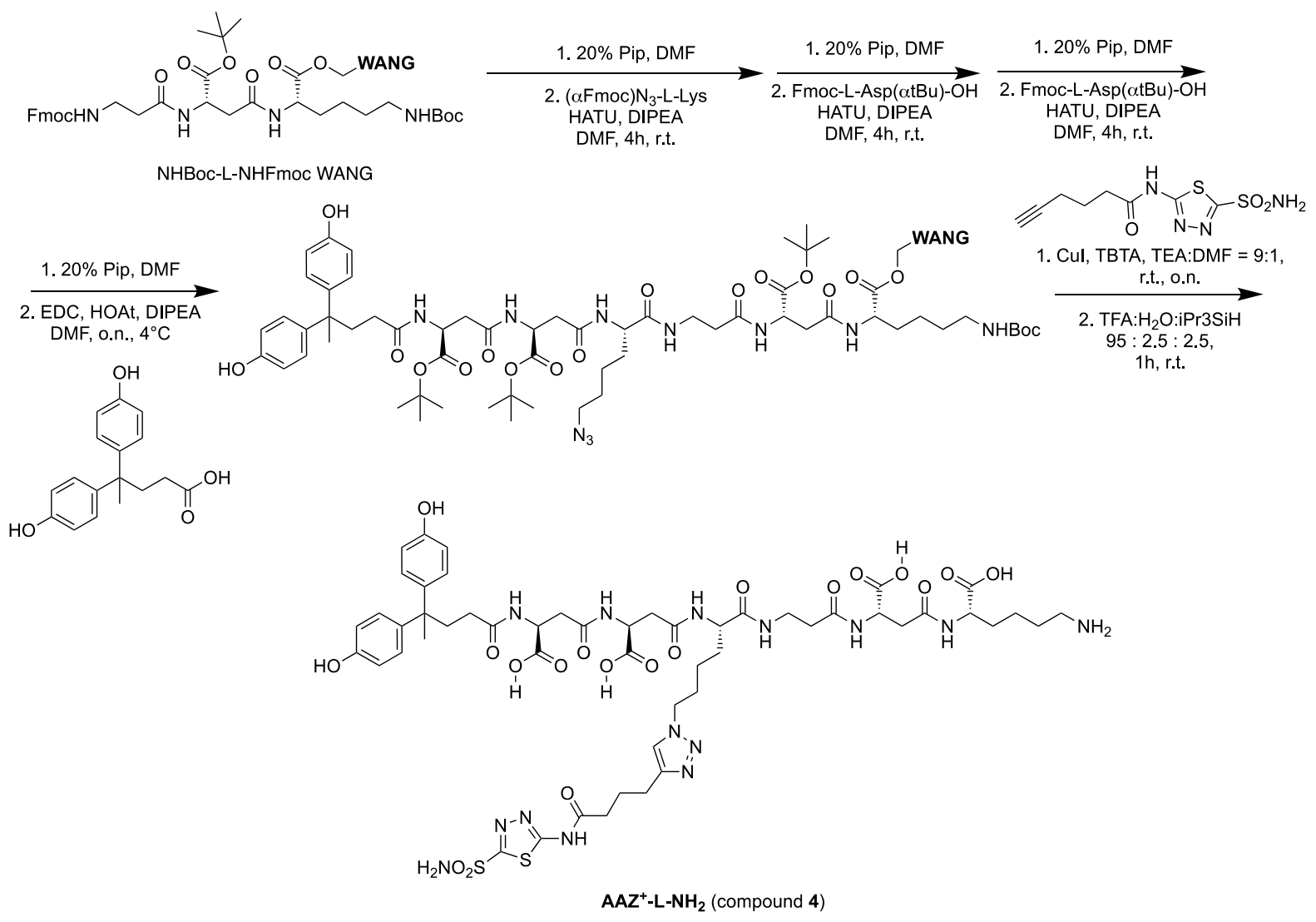

Figure S8. The synthesis steps for $A A Z^{+}-L-\mathrm{NH}_{2}$ are delineated.

Pre-synthesized NHBoc-L-NHFmoc WANG resin $(350 \mathrm{mg}, 0.175 \mathrm{mmol}$ ) was deprotected as reported in the general procedure. The peptide was assembled by adding in the order the following protected aminoacids: $\mathrm{N}^{2}$ (Fmoc)-N $\mathrm{N}^{6}$-diazo-L-lysine $(276 \mathrm{mg}, 0.7 \mathrm{mmol})$; Fmoc-L-

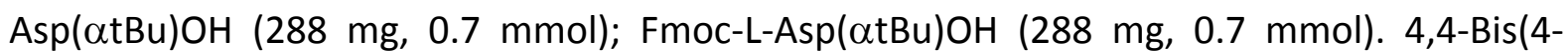
hydroxyphenyl)valeric acid (CAS: 126-00-1, $75 \mathrm{mg}, 0.26 \mathrm{mmol}$ ) was dissolved in $2 \mathrm{~mL}$ of dry DMF and activated at $4{ }^{\circ} \mathrm{C}$ by adding 1-ethyl-3-(3-dimethylaminopropyl)carbodiimide (EDC, $0.3 \mathrm{mmol}, 53 \mu \mathrm{L}$ ), 1-Hydroxy-7-azabenzotriazole (HOAt, $0.3 \mathrm{mmol}, 40 \mathrm{mg}$ ) and DIPEA (0.78 mmol, $156 \mu \mathrm{L}$ ) and added to the deprotected hexapeptide. The reaction was kept overnight at $4^{\circ} \mathrm{C}$, then the resin was washed several times with DMF.

Commercially available N-(5-sulfamoyl-1,3,4-thiadiazol-2-yl)hex-5-ynamide (192 mg, 0.7 mmol, CAS 1623789-42-3), copper lodide (Cul, $7 \mathrm{mg}, 0.035 \mathrm{mmol}$ ), Tris(benzyltriazolylmethyl)amine (TBTA, $37 \mathrm{mg}, 0.07 \mathrm{mmol}$ ) were dissolved in $2 \mathrm{~mL}$ of degassed DMF and added to the azido-peptide. The reaction was kept overnight at room temperature, then washed several times with EDA $(0.5 \mathrm{M}$ in water, $\mathrm{pH}=8)$ and fresh $\mathrm{DMF}$. The 
final product $4\left(\mathrm{AAZ}^{+}-\mathrm{L}-\mathrm{NH}_{2}\right)$ was cleaved from the resin and purified as previously described. MS calculated for $\mathrm{C}_{52} \mathrm{H}_{70} \mathrm{~N}_{14} \mathrm{O}_{19} \mathrm{~S}_{2}=1258.4383$, Mass detected (MS TOF ES + ) $=1259.4143$.

\section{Synthesis of 5-FITC labelled compounds}

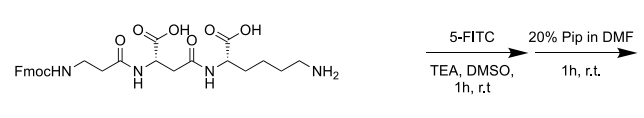

$\mathrm{NH}_{2} \mathrm{~L}-\mathrm{NHFmoc}$ (compound 1)

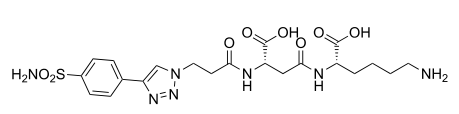

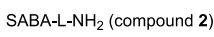

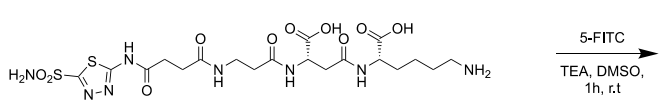

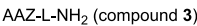

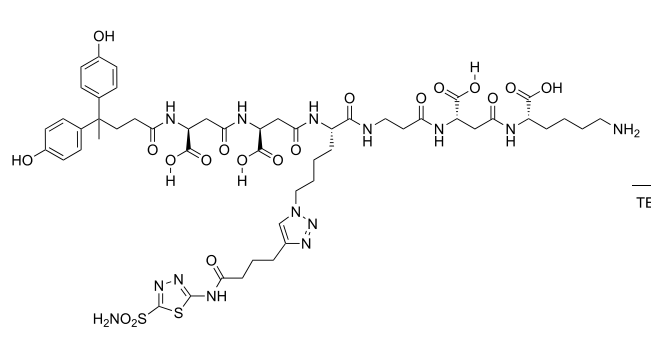

$\mathrm{AAZ}-\mathrm{L}-\mathrm{NH}_{2}$ (compound 4)

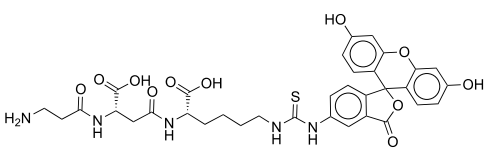

$\mathrm{NH}_{2} \mathrm{~L}-$ Fluo (compound 5)

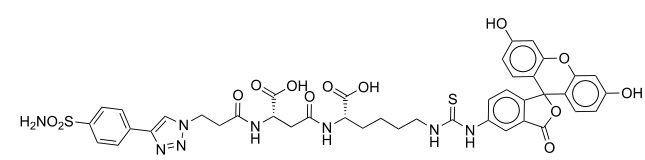

SABA-L-Fluo (compound 6 )

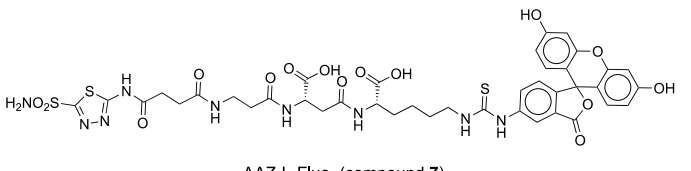

AAZ-L-Fluo (compound 7)

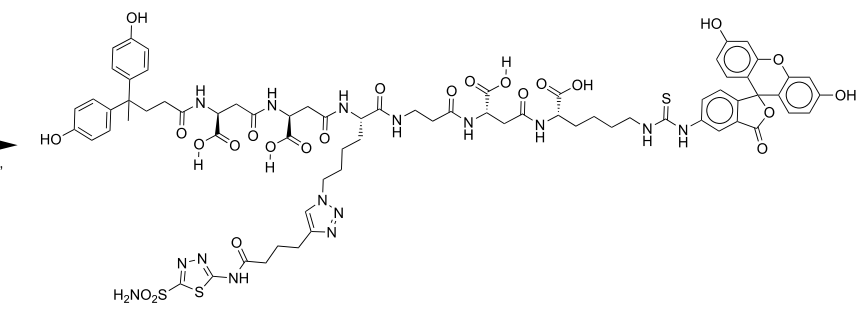

AAZ+-L-Fluo (compound 8)

Figure S9. A scheme describing the conjugation of fluorescein to each small molecule based bispecific adapter bridges.

The purified compounds were subsequently coupled to fluorescein isothiocyanate isomer I (5-FITC). Therefore, a solution of the respective compound (1.0 eq) in dry DMSO (200 $\mu \mathrm{L} /$ $1 \mathrm{mg}$ ) was allowed to react in the dark with 5-FITC (1.5 eq) and TEA (10.0 eq) for 1 hour at room temperature. After that, the reaction was stopped with the addition of formic acid (20.0 eq) and diluted to $1 \mathrm{ml}$ with a mixture of $\mathrm{MeCN}$ and $\mathrm{H}_{2} \mathrm{O}(1: 1)$ and purified over HPLC (95\% H2O / 5\% MeCN to $20 \% \mathrm{H} 2 \mathrm{O} / 80 \% \mathrm{MeCN}$ over $20 \mathrm{~min}$ ). After lyophilization the fluorescein derivatives were analysed by LC-MS TOF (ES).

\begin{tabular}{ccccc}
\hline Compound & Formula & MS calculated & ionization & MS detected \\
\hline $\mathrm{NH}_{2}$-L-Fluo (5) & $\mathrm{C}_{34} \mathrm{H}_{35} \mathrm{~N}_{5} \mathrm{O}_{11} \mathrm{~S}$ & 721.2054 & $\mathrm{ES}-$ & 720.2874 \\
SABA-L-Fluo (6) & $\mathrm{C}_{42} \mathrm{H}_{40} \mathrm{~N}_{8} \mathrm{O}_{13} \mathrm{~S}_{2}$ & 928.2156 & $\mathrm{ES}+$ & 927.1768 \\
AAZ-L-Fluo (7) & $\mathrm{C}_{40} \mathrm{H}_{41} \mathrm{~N}_{9} \mathrm{O}_{15} \mathrm{~S}_{3}$ & 983.1884 & $\mathrm{ES}+$ & 982.1185 \\
$\mathrm{AAZ}+$-L-Fluo (8) & $\mathrm{C}_{73} \mathrm{H}_{81} \mathrm{~N}_{15} \mathrm{O}_{24} \mathrm{~S}_{3}$ & 1647.4741 & $\mathrm{ES}+$ & 1647.3187 \\
\hline
\end{tabular}

Table S1. The theoretical and detected mass (MS) are illustrated in this table. 


\section{Appendix}

SABA-L-Fluo
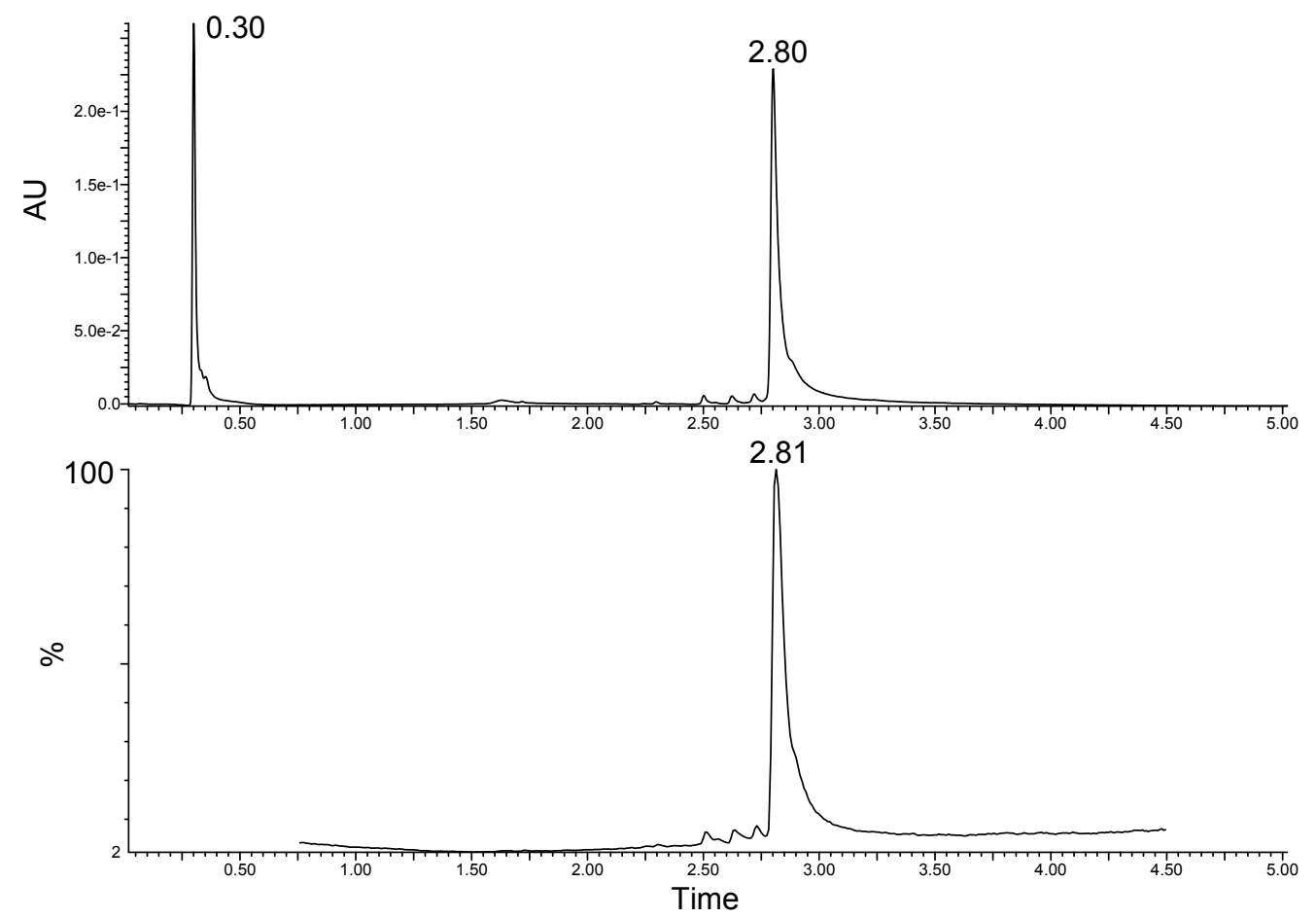

App. Figure1: LS-MS profile of SABA-L-Fluo at UV 260nm wavelength.

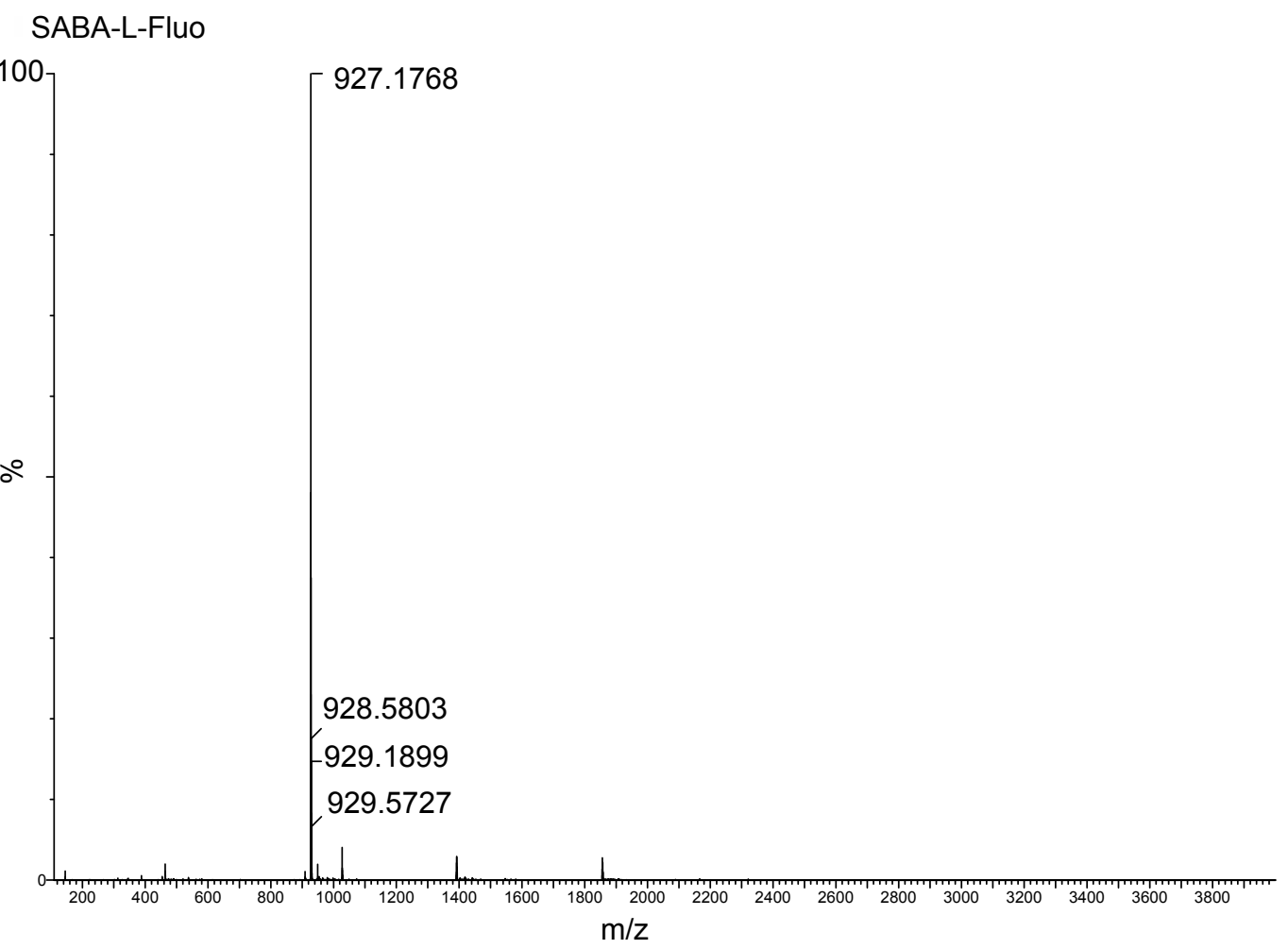

App. Figure 2: LS-MS profile of SABA-L-Fluo. 


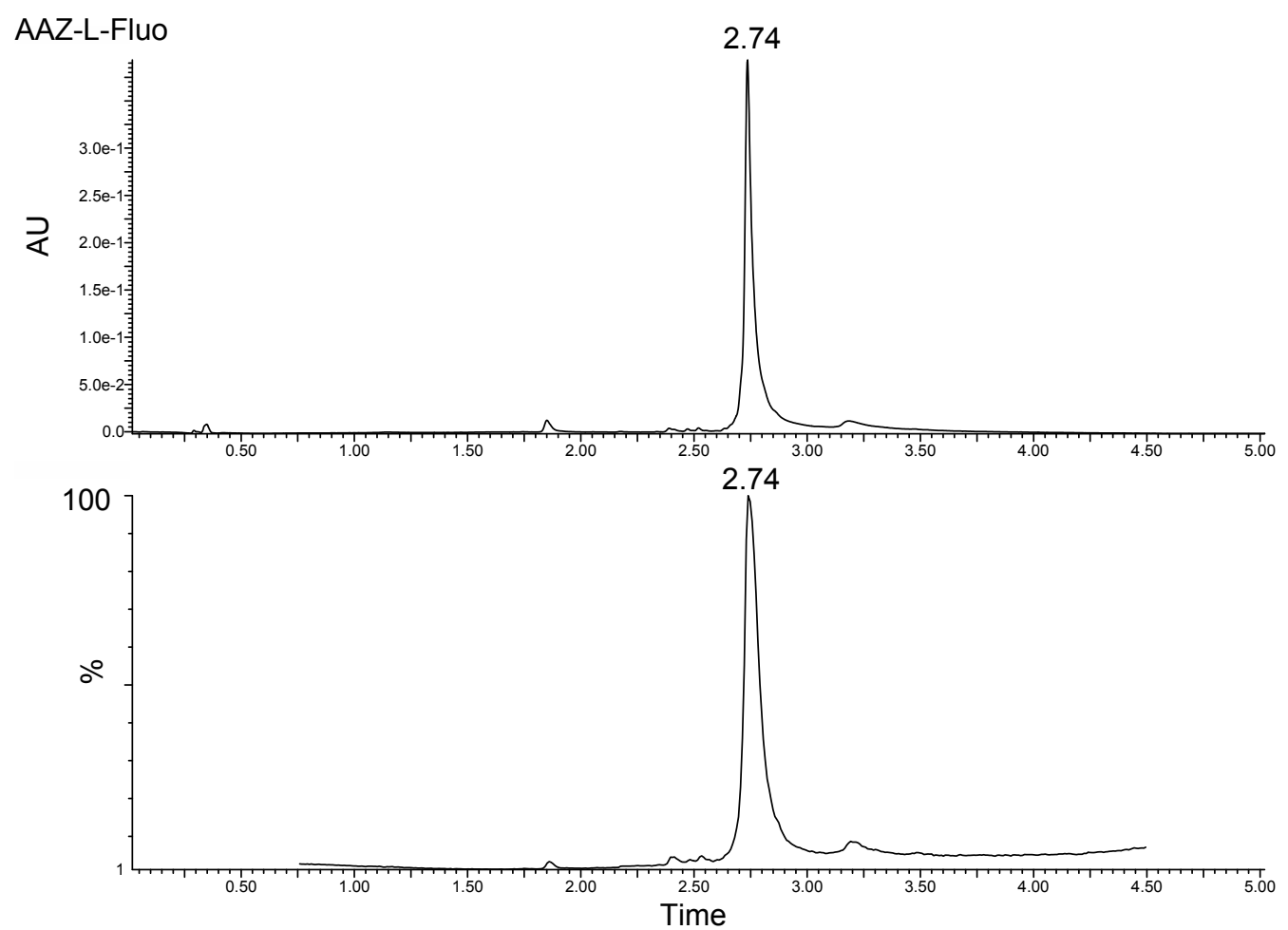

App. Figure 3: LS-MS profile of AAZ-L-Fluo at UV 260nm wavelength.

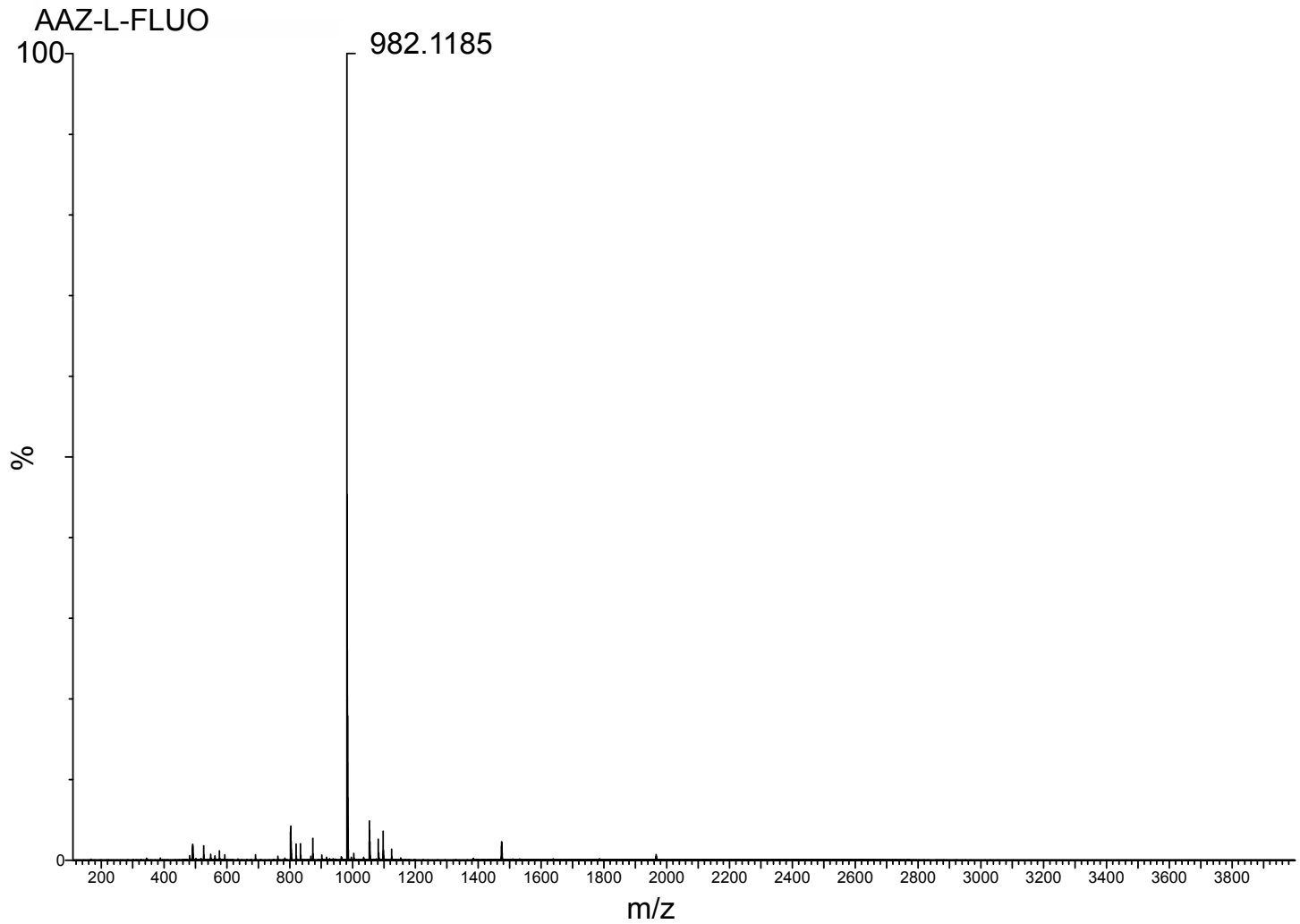

App. Figure 4: LS-MS profile of AAZ-L-Fluo. 


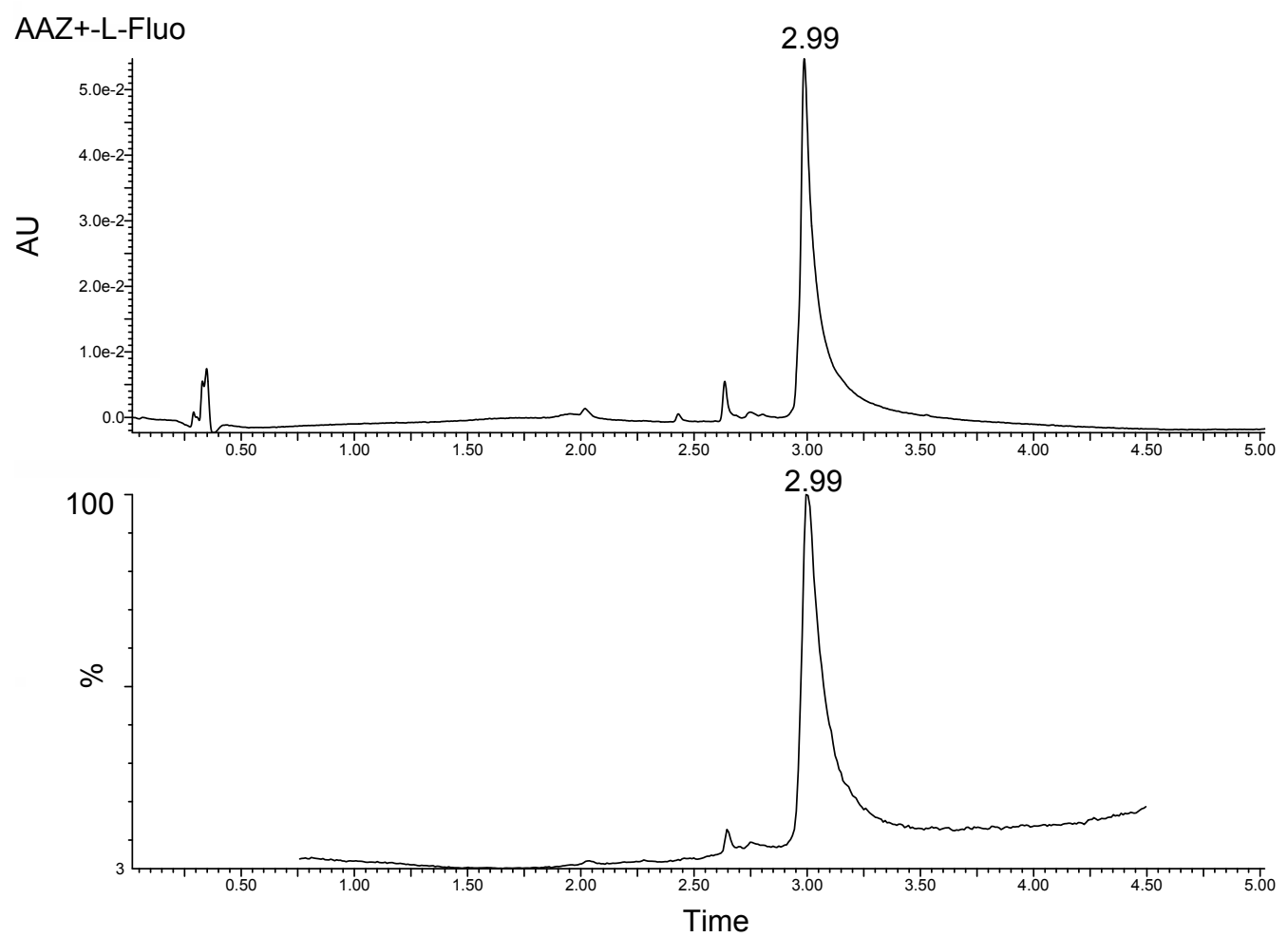

App. Figure 5: LS-MS profile of $A A Z^{+}-L-F l u o$ at UV 260nm wavelength.

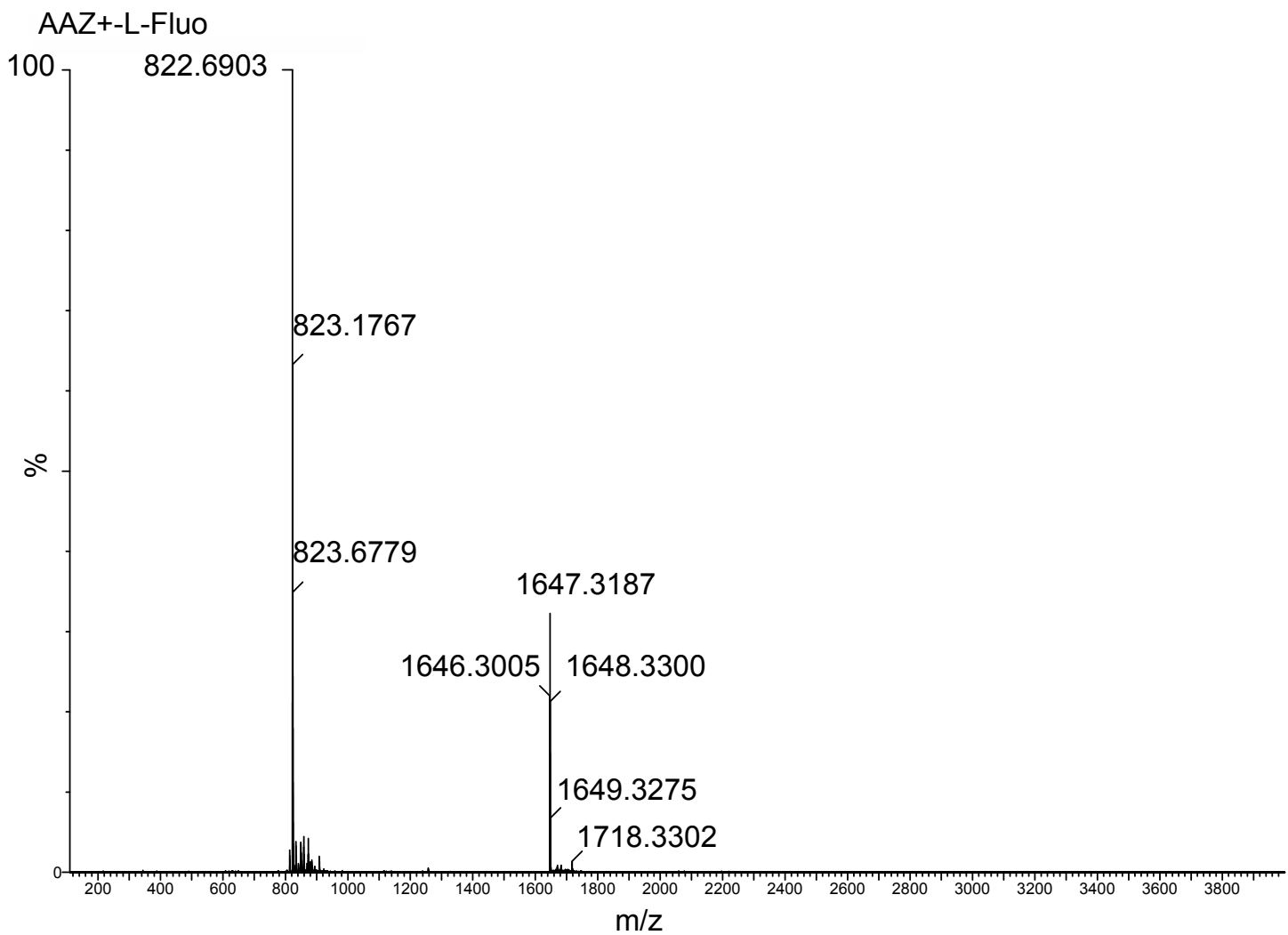

App. Figure 6: $L S-M S$ profile of $A A Z^{+}-L-F l u o$. 


\section{References}

1. Myburgh, R.; Kiefer, J. D.; Russkamp, N. F.; Simonis, A.; Pfister, S.; Magnani, C. F.; Wilk, C. M.; McHugh, D.; Friemel, J.; Müller, A. M.; Broek, M. v. d.; Becher, B.; Münz, C.; Neri, D.; Manz, M. G., Anti-human CD117 CAR T-cells efficiently eliminate CD117-expressing healthy and malignant hematopoietic cells. Leukemia 2020, in press.

2. Midelfort, K. S.; Hernandez, H. H.; Lippow, S. M.; Tidor, B.; Drennan, C. L.; Wittrup, K. D., Substantial energetic improvement with minimal structural perturbation in a high affinity mutant antibody. J Mol Biol 2004, 343 (3), 685-701.

3. Philip, B.; Kokalaki, E.; Mekkaoui, L.; Thomas, S.; Straathof, K.; Flutter, B.; Marin, V.; Marafioti, T.; Chakraverty, R.; Linch, D.; Quezada, S. A.; Peggs, K. S.; Pule, M., A highly compact epitope-based marker/suicide gene for easier and safer T-cell therapy. Blood 2014, 124 (8), 1277-87.

4. Hemmerle, T.; Probst, P.; Giovannoni, L.; Green, A. J.; Meyer, T.; Neri, D., The antibodybased targeted delivery of TNF in combination with doxorubicin eradicates sarcomas in mice and confers protective immunity. Br J Cancer 2013, 109 (5), 1206-13.

5. Pasche, N.; Wulhfard, S.; Pretto, F.; Carugati, E.; Neri, D., The antibody-based delivery of interleukin-12 to the tumor neovasculature eradicates murine models of cancer in combination with paclitaxel. Clin Cancer Res 2012, 18 (15), 4092-103.

6. Carnemolla, B.; Borsi, L.; Balza, E.; Castellani, P.; Meazza, R.; Berndt, A.; Ferrini, S.; Kosmehl, H.; Neri, D.; Zardi, L., Enhancement of the antitumor properties of interleukin-2 by its targeted delivery to the tumor blood vessel extracellular matrix. Blood 2002, 99 (5), 165965.

7. Cazzamalli, S.; Dal Corso, A.; Widmayer, F.; Neri, D., Chemically Defined Antibody- and Small Molecule-Drug Conjugates for in Vivo Tumor Targeting Applications: A Comparative Analysis. J Am Chem Soc 2018, 140 (5), 1617-1621.

8. Cazzamalli, S.; Ziffels, B.; Widmayer, F.; Murer, P.; Pellegrini, G.; Pretto, F.; Wulhfard, S.; Neri, D., Enhanced Therapeutic Activity of Non-Internalizing Small-Molecule-Drug Conjugates Targeting Carbonic Anhydrase IX in Combination with Targeted Interleukin-2. Clin Cancer Res 2018, 24 (15), 3656-3667. 